\title{
Cimarron Taro Xanthosoma Cubense (Schott) Schott: Endemic Cuban Species in Situ Conserved
}

\author{
Marilys Milián Jiménez* \\ PhD. Geneticist. Instituto de Investigaciones de Viandas Tropicales (INIVIT), Cuba
}

*Corresponding author: Marilys Milián Jiménez, PhD. Geneticist. Instituto de Investigaciones de Viandas Tropicales (INIVIT),

Apdo. 6, CP 53000, Santo Domingo, Villa Clara, Cuba

\begin{tabular}{|c|c|}
\hline ARTICLE INFO & ABSTRACT \\
\hline Received: 㓞 May 21, 2019 & Citation: Marilys Milián Jiménez. Cimarron Taro Xanthosoma Cubense (Schott) Schott: \\
\hline Published: May 28, 2019 & $\begin{array}{l}\text { Endemic Cuban Species in Situ Conserved. Biomed J Sci \& Tech Res 18(3)-2019. BJSTR. } \\
\text { MS.ID.003140. }\end{array}$ \\
\hline
\end{tabular}

\section{Introduction}

Specimens of cimarron taro (X. cubense) were collected in missions organized by INIVIT during the years 1989-1991 (Sánchez 1995) throughout the national territory and, in spite of several attempts, it was always possible its ex situ conservation (under field conditions) for short periods of time (up to three months maximum). After this time, the plants died as an indication of non-adaptation. For these reasons, the in-situ variant has been the priority to consider in the conservation of this important Cuban genetic resource. On the other hand, the main limitations to ensure an adequate conservation of genetic diversity in crops, such as taro are associated with the limited knowledge available on their taxonomy, as well as its life habits, its morphological and genetic characteristics. Taking into account also that despite this condition of endemism, cimarron taro is little known in Cuba and that have been presented in a general way, levels of genetic erosion in the ecosystems as a result of current and evident changes in the climate, it has been necessary to identify in situ specimens of this species, characterize it and encourage its conservation in its own habitat, not only because of its genetic interest, but also because of the need to study its potential for possible uses. All of the above constitute objectives of this work.

\section{Materials and Methods}

To identify in situ specimens of the species, previous reports by Sánchez et al. [1] who found specimens in the eastern Cuban region during plant collection missions organized by the INIVIT / IBPGR, as well as previous studies by Arias (1994) regarding the location and distribution of $X$. cubense in the Cuban national territory.
A collection mission was organized to Sierra de Cubitas, province of Camagüey, as one of these places previously referred to as sites with a natural and wild presence of the species. Once in the place, Paso de los Paredones, an exhaustive exploration of the area was carried out with the Chief of the Protected Area. A training action was also carried out with the workers of this Area in order to sensitize the personnel in charge of the maintenance and conservation of the flora of the place about the value of this plant species, and the importance of its conservation in that privileged geographical area for its vegetation. The genetic material found was characterized in the same place with the use of the list of descriptors for the genus Xanthoma [2,3].

A strategy was proposed for the in-situ conservation of $X$. cubense in the explored area, in accordance with the requirements of the species and the requirements of Limones - Tuabaquey Protected Area, Camagüey.

The appearance of possible damages caused by pests or abiotic factors was evaluated, as well as the presence of inflorescences in natural conditions that allowed to assess their genetic potentialities. It was also inquired about consumption habits, other uses or preferences.

\section{Results and Discussion}

A map is shown where the area sampled in this work is reflected, and references of the material studied (Figures $1 \& 2$ ). This location was also reported by Sánchez et al. \& Arias [1]. 


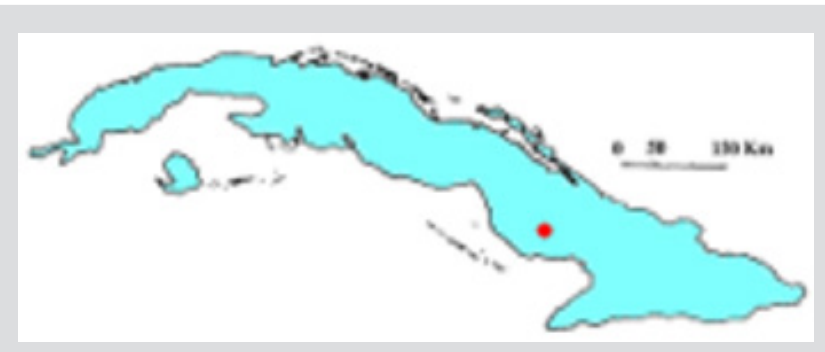

Figure 1: Geographic location found for Xanthosoma cubense (Schott) Schott in the province of Camagüey, Cuba.

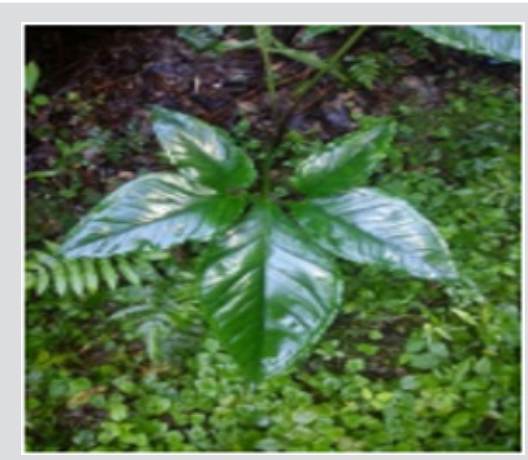

Figure 2: The plants died as an indication of nonadaptation.

\section{Central Cuba}

Camagüey: Sierra de Cubitas, Hoyo de Bonet, April 25, 1984, / Bisse, J. Gutiérrez, K.F. Günther, F.K. Meyer, B. Mory, C. Sánchez, R. Rankin et. Arias n. 53923 (HAJB); Sierra de Cubitas, Hoyo de Bonet, October 9, 1985, R. Oviedo n. 59654 (HAJB); Sierra de Najasa, Loma de Santa Águeda, July 12, 1986, E. Méndez and J. Rodríguez s.n. (HAJB) [4]. The present work allowed to identify specimens in the wild natural state of the species X. cubense in Sierra de Cubitas, belonging to the Protected Area Limones - Tuabaquey, Camagüey, conserved in situ in the Paso de los Paredones in the front and after the obelisk dedicated to the General Manuel de Quesada and Loynaz. A population of 26 plants in different stages was observed, only two adults that grow on a leached red Ferralitic soil. It is important to point out that since 1990, when it was collected there [1], specimens can be seen growing in the same place, that is to say, the right part of Paso de los Paredones coexisting with a type of fern. In this area a humid climate predominates where, practically, the sun's rays do not reach.

The fact that it is still in places where it was found in 1992 [1] and in 1994 (Arias, 1994) indicates that there has not been genetic erosion of the species, although a limited number of specimens are observed in the area. Even though consumption habits, other uses or preferences are not reported, it is important to consider that the fact of being an endemic Cuban wild species, in which no damage is observed by pests that emit inflorescence [1], among other qualities, make it a potentially valuable genetic resource for the Program of Genetic Breeding of Aroids in Cuba.

\section{Characterization}

After the geographical location and the identification of $X$. cubense specimens, a morphological characterization of five of them was carried out with the application of the List of descriptors for Xanthosoma spp. (IBPGR, 1989), modified by Milián (2008). According to Arias (1994), Xanthosoma cubense was the first species of this genus described in Cuba. León (1946) reports two endemic species for Cuba: Xanthosoma cubense (A. Rich.) Schott and Xanthosoma clarense León [5]. However, Arias (1994), after a careful review of the existing literature on the genus and herbarium material from Cuba deposited in several herbaria, has highlighted that both species should be considered as belonging to a single taxon ( $X$. cubense), whose interpretation has been the cause of some taxonomic errors. It belongs to the family Araceae and it is wild in all Cuban provinces, in humid places, at the foot of the calcareous mountains and among the rocks. In some places they call it "malanguilla". Its leaves are lobadas - pedadas. Subsequently, prior coordination with the Flora and Fauna Company, Limones Protected Area - Tuabaquey, Camagüey, a strategy was organized to guarantee the preservation of this valuable germplasm, through the in-situ modality of conservation of genetic resources [6].

\section{Strategy}

a) Train the staff

b) Mark plots identifying the place where the plant population is.

The conservation of biodiversity is strategic to satisfy the growing current and future demands of the world population. A strategy of this nature has as essential objectives, to conserve the variability of a species and to provide the breeders, the raw material for the selection programs.

\section{Conclusion}

a) The conservation of biodiversity in general, and in particular of the X. cubense species, is strategic to satisfy the demands of the world population.

b) The in-situ germplasm conservation variant responds to the need to guarantee the plant genetic heritage.

\section{References}

1. Sánchez (1995) Prospection of roots and tubers in Cuba in the year 1991. Rev Tropical crops 16 (1): 84-87.

2. IBPGR (1989) Descriptors for Xanthosoma. International Board for Plant Genetic Resources, Rome.

3. Milián M (2008) Characterization of the variability of the cultivars of the Cuban germplasm collection of the genus Xanthosoma (Araceae). Thesis presented as an option to the scientific degree of Doctor of Biological Sciences. Faculty of Biology, University of Havana - Institute of Tropical Viandas Research (INIVIT) Cuba 122 P. 
4. Arias GI (1998) Araceae. Fascicle 1/1. In: Flora of the Republic of Cuba Series A. Vascular plants. Koeltz Scientific Books. Koenigstern / Federal Republic of Germany p. 46.

5. León, hno (1946) Flora of Cuba, 1 Gymnosperms. Monocotyledons Contr Ocas Mus Hist Nat College "De La Salle" 8.

\section{ISSN: 2574-1241}

DOI: 10.26717/BJSTR.2019.18.003140

Marilys Milián Jiménez. Biomed J Sci \& Tech Res

(C) This work is licensed under Creative

Submission Link: https://biomedres.us/submit-manuscript.php
6. López Zada M, Vázquez E and López Fleites R (1995) Roots and tubers. Havana city. Ed. People and Education 2 Malanga 98-162: 312.

$\begin{array}{ll}\text { BIOMEDICAL } & \text { Assets of Publishing with us } \\ \text { RESEARCHES } & \text { - Global archiving of articles } \\ & \text { - Immediate, unrestricted online access } \\ \end{array}$

